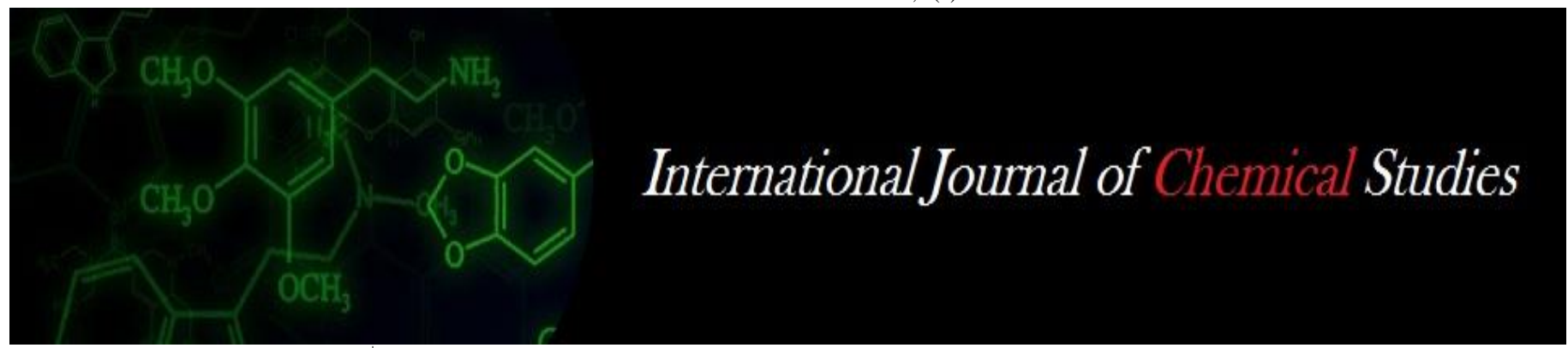

P-ISSN: 2349-8528

E-ISSN: 2321-4902

IJCS 2020; 8(1): 2135-2139

(C) 2020 IJCS

Received: 22-11-2019

Accepted: 24-12-2019

\section{KS Dhami}

ICAR-Indian Agricultural

Research Institute, New Delhi, India

\section{VR Sagar}

ICAR-Indian Agricultural

Research Institute, New Delhi, India

\section{Alemwati Pongener}

ICAR-National Research Centre on Litchi, Muzaffarpur, Bihar, India
Corresponding Author: KS Dhami

ICAR-Indian Agricultural Research Institute, New Delhi, India

\section{Impact of pack-house chemicals treatments on quality of litchi during low temperature storage}

\author{
KS Dhami, VR Sagar and Alemwati Pongener
}

DOI: https://doi.org/10.22271/chemi.2020.v8.i1af.8585

\begin{abstract}
An experiment was conducted to study the impact of chemical treatments on postharvest quality attributes of freshly harvested litchi fruits. Litchi variety "Shahi" fruits were harvested at full maturity (ready-to-eat) from the orchard of National Research Centre for Litchi, Muzaffarpur, Bihar and transported to IARI, New Delhi where treated with sodium hypochlorite $(0.2 \%)$, sodium hypochlorite $(0.2 \%)+$ carnauba wax $(10 \%)$, sodium hypochlorite $(0.2 \%)+$ KMS $(0.5 \%)$, sodium hypochlorite $(0.2 \%)$ + KMS $(0.6 \%)$, sodium hypochlorite $(0.2 \%)+$ sodium chlorite $(0.05 \%)$, sodium hypochlorite $(0.2 \%)+$ sodium chlorite $(0.06 \%)$ along with control and packed in punnets for storage study at $2{ }^{\circ} \mathrm{C}$ and $85-90 \%$ RH. The observations related to quality parameters were recorded at 5 days intervals. The results revealed that all treatments reduced pericarp browning. Sodium hypochlorite $(0.2 \%)$ in combination with KMS $(0.5 \%)$ treated fruits were found most effective in retaining higher amount of moisture content, total soluble solids, reducing sugars, anthocyanin content and good sensory attributes in the fruits leading to lowest browning index with an extended shelf life up to 25 days. These findings confirmed that treatment with sodium hypochlorite $(0.2 \%)$ followed by KMS $(0.05 \%)$ could be used as alternative method to reduce pericarp browning and quality deterioration of litchi fruit during low temperature storage.
\end{abstract}

Keywords: Litchi, pericarp browning, fruit quality, potassium metabisulfite, sodium chlorite, sodium hypochlorite, carnauba wax

\section{Introduction}

Litchi (Litchi chinensis Sonn.) is the most renowned edible fruit of soapberry family, Sapindaceae, known for its attractive deep red colour, nutritive value, deliciously flavoured translucent juicy aril and refreshing taste. Litchi is an excellent source of vitamin $\mathrm{C}$ with high content in minerals like potassium, phosphorous, magnesium and calcium. It may be eaten fresh, frozen, canned in syrup or dried to produce "litchi nuts". It is cultivated in China, India, Thailand, Taiwan and South Africa. India is the second largest producer of litchi in the world after China. Major producing states are Bihar (40\% of total production), West Bengal, Jharkhand, Assam, Punjab and Uttaranchal.

The fruits are harvested at ripe stage which is judged by the development of red colour on the fruit pericarp and flattening of tubercles. Within 2-3 days after harvesting of the fruits, the red colour of the pericarp turn brown, this drastically reduces the commercial value of the fruits. The rapid enzymatic degradation of anthocyanin pigments is believed to be the main causes of browning of pericarp (Jiang et al., 2000) ${ }^{[6]}$. The pericarp browning initially occurs on protuberances and then extends over the entire surface of pericarp but mainly in epicarp and upper layers of mesocarp. Water loss or dehydration causes rapid loss of membrane integrity which leads to interactions of substrate with various enzymes such as peroxidase (POD), polyphenol oxidase (PPO), anthocyanase and phenylalanine ammonia lyase (PAL). The major browning takes place upon bringing the enzymes (e.g. PPO) in close contact with the proposed substrate (e.g. -epicatechin) to initiate browning reaction (Sun et al., 2006) ${ }^{[18]}$. It is worth mention that the substrates of PPO are not completely characterized. Peroxidase activity coupled with ascorbic acid oxidation also enhances anthocyanin degradation. All these enzymatic reactions ultimately lead to the formation of polymeric brown pigments involving colored o-quinones as browning precursors (Wang et al., 2010) ${ }^{[19]}$. Fruit moisture loss during storage and holding typically reduces visual appeal, marketable/saleable value and sensory qualities also. The main reasons for pericarp browning are desiccation, mechanical injury 
and microbial or pathogenic infection. These all, by one and another way responsible for rise in $\mathrm{pH}$, reduced membrane fluidity, increased membrane permeability, loss of compartmentation between enzymes and their substrates and thereby, may aid enzymatic browning of pericarp.

Numerous approaches have been tried since the time of commercialization of this fruit but each approaches has it's certain limitations either relating to tedious and costly method of applications or short duration effect or human health concern. Also, these approaches could not prove to be satisfactory in retaining the desirable color of litchi. According to review literature, the combinatorial application of chemicals alone or with edible coatings by dip or spray method may maintain the quality of fruit for a longer time which will thus help in extending the marketability of litchi for a prolonged period. Accordingly, some of the chemicals such as sodium hypochlorite were used as a treatment due to its acidic nature as well as disinfectant and fungicidal property (Cerioni et al., 2009) ${ }^{[4]}$ and coating treatments like carnauba-based wax, which are known to maintain the quality of stored fruit crops by suppressing moisture loss, improving the strength of peel tissue and retaining volatile components and controlling ripening by modifying $\mathrm{CO}_{2}$ and $\mathrm{O}_{2}$ concentrations inside the fruit (Baldwin et al., 1996) ${ }^{[3]}$ were tried. The potassium metabisulphite (KMS) as a source of $\mathrm{SO}_{2}$ which acts as antimicrobial and antioxidant have been used since it is reported to inhibit browning in several fruits (Milne and Johnson, 1994) ${ }^{[14]}$. Sodium chlorite (SC) is an oxidising and sanitising agent which is able to generate chlorine dioxide $\left(\mathrm{ClO}_{2}\right)$ in an acidic environment which was reported to reduce enzymatic browning of fruits and vegetables (Liu et al., 2006) ${ }^{[18]}$. In our present study, it has been evaluated the possibility of using these chemicals and edible coating as combinational application for inhibiting the pericarp browning of litchi fruits during low temperature storage.

\section{Materials and Methods}

Litchi fruits (cv. Shahi) were harvested from the orchard of National Research Centre on Litchi, Muzaffarpur, Bihar when $90-95 \%$ of peel color was red color. After sorting and grading, the fruits were transported to Division of Food Science and Post Harvest Technology laboratory, IARI, New Delhi in CFB boxes within 28 hours of harvest and again sorting was done to remove the spoiled fruits. Then the fruits were treated with T1: sodium hypochlorite $(0.2 \%)$, T2: sodium hypochlorite $(0.2 \%)+$ carnauba wax $(10 \%)$, T3: sodium hypochlorite $(0.2 \%)+\mathrm{KMS}(0.5 \%)$, T4: sodium hypochlorite $(0.2 \%)+\operatorname{KMS}(0.6 \%)$, T5: sodium hypochlorite $(0.2 \%)+$ sodium chlorite $(0.05 \%)$, T6: sodium hypochlorite $(0.2 \%)+$ sodium chlorite $(0.06 \%)$, T7: control; by dipping the fruits in solution for 5 minutes followed by next chemical/edible coating as treatment. The fruits were dried for 10 minutes prior to application of next treatment. The treated fruits were then packed in CFB boxes and stored at $2{ }^{\circ} \mathrm{C}$ and $85-90 \%$ relative humidity. The fruit samples were analyzed for physio- chemical attributes for every 5 days interval till the fruits became unacceptable.

\section{Weight loss}

Weight loss was determined by weighing the fruits at different intervals which were calculated as the difference between the initial weight and the final weight at the time of measurement and expressed as the percentage of initial fruit weight.

\section{Browning Index}

Browning of litchi pericarp was accessed visually by measuring the total browned area on the pericarp by using following scale: $0=$ no browning (excellent quality); $1=$ slight browning; $2=<1 / 4$ browning (marketable quality); $3=$ $1 / 4-1 / 2$ browning; $4=1 / 2-1 / 3$ browning and $5=>1 / 3$ browning (poor quality). The browning index was calculated as $\sum$ (browning scale $\mathrm{x}$ percentage of corresponding fruits within each class).

\section{Total anthocyanin content}

Total anthocyanin in the fruit pericarp was determined by the pH-differential method using two buffers: potassium chloride buffer (pH- 1.0) and sodium acetate buffer (pH- 4.5). First, the pigments were extracted from $2 \mathrm{~g}$ fruit pericarp by slicing and crushing using $80 \%$ ethanol and done centrifugation at $10,000 \mathrm{rpm}$ for $10 \mathrm{~min}$ where obtained supernatants were diluted in $\mathrm{pH} 1.0$ and $\mathrm{pH} 4.5$ buffers for taking the observations at 520 and $700 \mathrm{~nm}$ in a spectrophotometer. Finally, the anthocyanin content was calculated in terms of cyanidin-3-glucoside equivalent which was expressed as $\mathrm{mg} / 100 \mathrm{~g}$ of fresh pericarp weight using molar absorption coefficient of $26,900 \mathrm{~L} / \mathrm{mol} / \mathrm{cm}$ and a molecular weight of $449.2 \mathrm{~g} / \mathrm{mol}$.

\section{Total soluble solid and reducing sugars}

Total soluble solid was analyzed by putting few drops of the sample slurry over the prism of the hand refractometer (Fisher $0-50$, Japan) and the reading was recorded in ${ }^{\circ} \mathrm{B}$. Reducing sugars were estimated by titration against boiling Fehling solution A and B using methylene blue as an indicator till brick red colour appears as the end point.

\section{Sensory evaluation}

The sensory quality evaluation of the litchi fruits was done by a semi trained panel of 7 judges and aged 25-45 years from both of the genders, using a 9 point Hedonic scale (Amerine et al. 1965) ${ }^{[1]}$.

\section{Statistical Analysis}

The experiment was conducted in a factorial completely randomized design with three replications, each replication having 50 fruits. The data were analyzed using the WASP 2.0 (Web Agri Stat Package) and the results were compared from ANOVA by calculating the critical difference (CD) at $5 \%$ level of significance.

\section{Results and Discussion}

Pericarp browning is the main factor influencing post-harvest quality and storage life of litchi fruits. The PLW of the fruits increased with the increasing storage period. The lower PLW in KMS $(0.5 \%)$ treated fruits may be due to $\mathrm{SO}_{2}$ liberated by KMS which possibly had maintained cell integrity and permeability of tissues, thereby hindering the loss of moisture from the fruit surface. Similar results were obtained in litchi fruits by Khan et al., $2012^{[8]}$. Furthermore, higher PLW in control fruits may be due to higher metabolic activity than treated fruits. 
Table 1: Effect of treatments on PLW (\%) of litchi fruits during storage $\left(2{ }^{\circ} \mathrm{C}\right.$ and $\left.85-90 \% \mathrm{RH}\right)$

\begin{tabular}{|c|c|c|c|c|c|c|c|c|c|c|c|c|c|c|c|}
\hline \multirow{2}{*}{ Treatments } & \multicolumn{14}{|c|}{ Storage (days) } & \multirow[b]{2}{*}{ Mean } \\
\hline & $\mathbf{0}$ & 2 & 4 & 6 & 8 & 10 & 12 & 14 & 16 & 18 & 20 & 22 & 24 & 26 & \\
\hline $\mathrm{NaO}$ & $0^{\circ}$ & $1.63^{n}$ & $4.92^{\mathrm{ji}}$ & $6.58^{\mathrm{ycx} x a z}$ & $7.42^{\text {vuw }}$ & $8.25^{\text {rst }}$ & $9.09^{\mathrm{kmpqnol}}$ & $9.6^{\mathrm{kmijhl}}$ & $10.22^{\mathrm{gfh}}$ & \begin{tabular}{l|l}
$10.7^{4 e f}$ \\
\end{tabular} & $1.34^{\mathrm{ed}}$ & $11.87^{\mathrm{cd}}$ & $12.29^{\mathrm{cb}}$ & $12.6^{\mathrm{cb}}$ & $8.25^{\mathrm{b}}$ \\
\hline & & $1.98^{\mathrm{n}}$ & $3.61^{\mathrm{m}}$ & $5.50^{\text {ghefi }}$ & $5.96^{\text {cefd }}$ & $6.42^{\text {cbadz }}$ & $6.88^{\text {yvxbawz }}$ & yvxuwz & $5^{\text {sut }}$ & $8.25^{\mathrm{rst}}$ & $1^{\text {rpqo }}$ & $9.21^{\mathrm{kmpjnol}}$ & $9.71^{\text {kgijhl }}$ & $9.91^{\mathrm{gijh}}$ & $.51^{\mathrm{c}}$ \\
\hline $\mathrm{KI}$ & & $1.76^{\mathrm{n}}$ & $3.471^{\mathrm{m}}$ & $5.21^{\text {ghjfi }}$ & $5.71^{\text {ghefd }}$ & $6.32^{\mathrm{cbd}}$ & $7.20^{\text {yvxuw }}$ & $7.41^{\text {vuw }}$ & $7.88^{\text {sut }}$ & $8.33^{\mathrm{rsqt}}$ & $8.73^{\text {rpqno }}$ & $9.17^{\mathrm{kmpjnol}}$ & $9.50^{\mathrm{kmijnhl}}$ & ggijhl & $6.46^{\mathrm{c}}$ \\
\hline $\mathrm{KM}$ & & $1.54^{\mathrm{n}}$ & $3.09^{\mathrm{m}}$ & $4.72^{\mathrm{jk}}$ & $5.37^{\text {ghfi }}$ & $5.75^{\text {ghefd }}$ & $6.23^{\text {cebd }}$ & $6.83^{\text {yxbawz }}$ & $7.32^{\mathrm{vxuw}}$ & $\mathrm{v} 7.61^{\mathrm{vut}}$ & $8.37^{\mathrm{rsqt}}$ & $8.77^{\text {rpqno }}$ & $9.38^{\mathrm{kmijnol}}$ & $9.93^{\mathrm{gijh}}$ & $6.06^{\mathrm{e}}$ \\
\hline $\mathrm{NaClO}$ & & $1.81^{\mathrm{n}}$ & $3.44^{\mathrm{lm}}$ & $4.74^{\mathrm{ji}}$ & $5.17^{\text {ghji }}$ & $5.73^{\text {ghefd }}$ & $6.40^{\text {cbad }}$ & $6.91^{\mathrm{yvx}}$ & $7.32^{\text {vxuw }}$ & $7.75^{\text {sut }}$ & $8.24^{\mathrm{rst}}$ & $8.82^{\text {rpqno }}$ & $9.35^{\mathrm{kmijnol}}$ & $9.82^{\mathrm{kgijh}}$ & $6.10^{\mathrm{e}}$ \\
\hline $\mathrm{NaClO}$ & & $1.38^{\mathrm{n}}$ & $3.0^{\mathrm{m}}$ & $3.96^{\mathrm{lk}}$ & $5.15^{\text {ghji }}$ & $5.85^{\text {gcefd }}$ & $6.43^{\text {ycbadz }}$ & $7.16^{\text {yvxuawz }}$ & $7.84^{\text {sut }}$ & $8.46^{\text {rspq }}$ & $9.04^{\mathrm{mpqnol}}$ & $\begin{array}{l}1.60^{\mathrm{kmijhl}} \\
\mathrm{l}\end{array}$ & $10.0^{\text {gifh }}$ & $10.40^{\mathrm{gf}}$ & $6.30^{\mathrm{d}}$ \\
\hline & $0^{\circ}$ & $2.86^{\mathrm{m}}$ & $5.0^{\mathrm{hji}}$ & $5.85^{\text {gcefd }}$ & $6.35^{\mathrm{cbd}}$ & $7.62^{\text {vut }}$ & $8.91^{\text {rmpqno }}$ & kgijhl & $10.41^{\mathrm{gf}}$ & $11.23^{\mathrm{ed}}$ & $11.96^{\mathrm{cd}}$ & & & $14.4^{\mathrm{a}}$ & $8.96^{\mathrm{a}}$ \\
\hline ea & 1 & $1.85^{\mathrm{m}}$ & $3.78^{1}$ & $5.22^{\mathrm{k}}$ & $5.87^{\mathrm{j}}$ & $6.56^{\mathrm{i}}$ & $7.30^{\mathrm{h}}$ & & $8.40^{\mathrm{f}}$ & $8.91^{\mathrm{e}}$ & $9.48^{\mathrm{d}}$ & $10.02^{\mathrm{c}}$ & $10.55^{\mathrm{b}}$ & $10.97^{\mathrm{a}}$ & \\
\hline
\end{tabular}

* Means with same superscript are not significantly different.

$\mathrm{NaOCl}=$ Sodium hypochlorite, $\mathrm{CW}=$ Carnauba Wax, $\mathrm{KMS}=$ Potassium metabisulphite, $\mathrm{NaClO}_{2}=$ Sodium chlorite

Total soluble solids content increased in the initial upto 10 days of storage but thereafter it decreased as the storage period extended, in all the fruits which might be due to dehydration and conversion of starch and polysaccharides into simple sugars. Decrease in TSS might be due to biochemical activities like utilisation of reducing sugars and other organic metabolites (Marboh et al., 2012) ${ }^{[12]}$. However, lower TSS in control fruits might be due to loss of sugars due to high rate of respiration (Jha et al., 1990) ${ }^{[5]}$.

A decline in reducing sugars content was observed in fruits which might be due to utilization of sugars for respiration. The data also revealed that fruits treated with $\mathrm{CW}$ retained higher reducing sugars $(8.6 \%)$ on the last day which might be due to modified atmospheric condition in $\mathrm{CW}$ treated fruits which might have reduced the respiration rate.

Table 2: Effect of treatments on TSS $\left({ }^{\circ} \mathrm{B}\right)$ of litchi fruits during storage $\left(2{ }^{\circ} \mathrm{C}\right.$ and $\left.85-90 \% \mathrm{RH}\right)$

\begin{tabular}{|c|c|c|c|c|c|c|c|}
\hline \multirow{2}{*}{ Treatments } & \multicolumn{7}{|c|}{ Storage (days) } \\
\hline & $\mathbf{0}$ & 5 & 10 & 15 & 20 & 25 & Mean \\
\hline $\mathrm{NaOCl}(0.2 \%)$ & $17.5^{\mathrm{i}}$ & $18.0^{\text {fgeh }}$ & $18.5^{\text {bdac }}$ & $18.3^{\text {fbdec }}$ & $18.2^{\text {fgdec }}$ & $17.9^{\text {fgih }}$ & $18.06^{\mathrm{c}}$ \\
\hline CW $(10 \%)$ & $17.5^{\mathrm{i}}$ & $17.8^{\text {ghi }}$ & $18.4^{\text {bdec }}$ & $18.2 \mathrm{f}^{\mathrm{gdec}}$ & $18.0^{\text {fgeh }}$ & $17.8^{\text {gih }}$ & $18.05^{\mathrm{c}}$ \\
\hline KMS $(0.5 \%)$ & $17.8^{\text {gih }}$ & $18.1^{\text {fgde }}$ & $18.5^{\text {bdac }}$ & $18.4^{\text {bdec }}$ & $18.1^{\text {fgde }}$ & $18.06^{\mathrm{fge}}$ & $18.16^{\mathrm{bc}}$ \\
\hline KMS $(0.6 \%)$ & $17.6^{\text {ih }}$ & $18.0^{\mathrm{fgeh}}$ & $18.5^{\text {bdac }}$ & $18.3^{\text {fbdec }}$ & $18.0^{\text {fgeh }}$ & $18.0^{\mathrm{fgeh}}$ & $18.07^{\mathrm{c}}$ \\
\hline $\mathrm{NaClO}_{2}(0.05 \%)$ & $17.8^{\text {gih }}$ & $18.2^{\mathrm{fgdh}}$ & $18.6^{\mathrm{bac}}$ & $18.5^{\text {bdac }}$ & $18.1^{\text {fgde }}$ & $18.1^{\text {fgde }}$ & $18.21^{\text {ba }}$ \\
\hline $\mathrm{NaClO}_{2}(0.06 \%)$ & $18.0^{\text {fgeh }}$ & $18.3^{\mathrm{fbdec}}$ & $18.7^{\mathrm{ba}}$ & $18.5^{\text {bdac }}$ & $18.0^{\text {fgeh }}$ & $18.1^{\text {fgde }}$ & $18.27^{\mathrm{ba}}$ \\
\hline Control & $18.1^{\text {fgde }}$ & $18.5^{\text {bdac }}$ & $18.9^{\mathrm{a}}$ & $18.3^{\mathrm{fbdec}}$ & $18.2^{\text {fgdec }}$ & $17.9^{\text {fgih }}$ & $18.33^{\mathrm{a}}$ \\
\hline Mean & $17.75^{\mathrm{e}}$ & $18.13^{\mathrm{c}}$ & $18.58^{\mathrm{a}}$ & $18.35^{\mathrm{b}}$ & $18.19^{c}$ & $17.97^{\mathrm{d}}$ & \\
\hline
\end{tabular}

* Means with same superscript are not significantly different.

Table 3: Effect of treatments on reducing sugars (\%) of litchi fruits during storage $\left(2{ }^{\circ} \mathrm{C}\right.$ and $\left.85-90 \% \mathrm{RH}\right)$

\begin{tabular}{|c|c|c|c|c|c|c|c|}
\hline \multirow{2}{*}{ Treatments } & \multicolumn{7}{|c|}{ Storage (days) } \\
\hline & $\mathbf{0}$ & 5 & 10 & 15 & 20 & 25 & Mean \\
\hline $\mathrm{NaOCl}(0.2 \%)$ & $9.4^{\text {ebdagcf }}$ & $9.3^{\text {ebidhagcf }}$ & $9.0^{\text {ejidhlgf }}$ & $8.6^{\mathrm{jmoln}}$ & $8.4^{\text {pmoqn }}$ & $8.0^{\mathrm{pq}}$ & $8.7^{\mathrm{b}}$ \\
\hline $\mathrm{CW}(10 \%)$ & $9.6^{\text {bdac }}$ & $9.3^{\text {ebidhagcf }}$ & $9.2^{\text {ejbidhagcf }}$ & $8.9^{\text {ejmihlgnf }}$ & $8.7^{\text {jmioln }}$ & $8.6^{\mathrm{moln}}$ & $9.0^{\mathrm{a}}$ \\
\hline KMS $(0.5 \%)$ & $9.8^{\mathrm{a}}$ & $9.5^{\text {bdac }}$ & $9.3^{\text {ebidhagcf }}$ & $9.2^{\text {ejbidhagcf }}$ & $8.8^{\text {jmihlgn }}$ & $8.5^{\mathrm{pmoln}}$ & $9.2^{\mathrm{a}}$ \\
\hline KMS $(0.6 \%)$ & $9.7^{\mathrm{ba}}$ & $9.5^{\text {ebdac }}$ & $9.3^{\text {ebidhagcf }}$ & $9.1^{\text {ejbidhgcf }}$ & $8.7^{\text {jmiohln }}$ & $8.5^{\text {pmoln }}$ & $9.1^{\mathrm{a}}$ \\
\hline $\mathrm{NaClO}_{2}(0.05 \%)$ & $9.3^{\text {ebidhagcf }}$ & $8.9^{\text {ejidhlgf }}$ & $8.7^{\text {jmioln }}$ & $8.5^{\mathrm{pmoln}}$ & $8.2^{\text {poqn }}$ & $8.2^{\text {poqn }}$ & $8.6^{\mathrm{b}}$ \\
\hline $\mathrm{NaClO}_{2}(0.06 \%)$ & $9.4^{\text {ebdhagcf }}$ & $9.0^{\text {ejidhlgf }}$ & $8.8^{\text {jmihlgnf }}$ & $8.6^{\mathrm{jmoln}}$ & $8.4^{\text {pmoqn }}$ & $8.2^{\text {poqn }}$ & $8.7^{\mathrm{b}}$ \\
\hline Control & $9.5^{\text {ebdacf }}$ & $9.2^{\text {ejbidhagcf }}$ & $9.0^{\text {ejidhlgf }}$ & $8.3^{\text {poqn }}$ & $8.2^{\text {poq }}$ & $7.8^{\mathrm{q}}$ & $8.6^{\mathrm{b}}$ \\
\hline Mean & $9.5^{\mathrm{a}}$ & $9.2^{\mathrm{b}}$ & $9.0^{c}$ & $8.7^{\mathrm{d}}$ & $8.4^{\mathrm{e}}$ & $8.2^{\mathrm{f}}$ & \\
\hline
\end{tabular}

* Means with same superscript are not significantly different.

It was found that there was degradation of anthocyanin pigments in all the treatments as the storage period extended. However, all the treatments delayed degradation of anthocynins in which KMS $(0.5 \%)$ treated fruits showed highest retention of anthocyanin which might be due to bleaching action of the chemical (KMS as a source of $\mathrm{SO}_{2}$ ) caused by nucleophilic ion reactions which might have resulted in the removal of its original colour and subsequent release of positive ions by anthocyanin, generating the red colour under acidic medium as reported Neog and Saikia (2010) ${ }^{[15]}$. They further elaborated that when sulphite causes reduction of oxygen, the oxidase cannot oxidise polyphenol or can't combine with quinines which cause inactivity of quinines to take part in the reaction. Thus, this hinders the oxidation of pericarp, thereby reducing the pericarp browning. Lower anthocyanin pigments in control fruits might be due to higher water loss and respiratory utilizations of substrates during storage.

Table 4: Effect of treatments on anthocyanin content (mg/100g) of litchi fruits during storage $\left(2{ }^{\circ} \mathrm{C}\right.$ and $\left.85-90 \% \mathrm{RH}\right)$

\begin{tabular}{|c|c|c|c|c|c|c|c|}
\hline \multirow{2}{*}{ Treatments } & \multicolumn{7}{|c|}{ Storage (days) } \\
\hline & $\mathbf{0}$ & 5 & 10 & 15 & 20 & 25 & Mean \\
\hline $\mathrm{NaOCl}(0.2 \%)$ & $38.5^{\mathrm{a}}$ & $30.5^{\text {ifgh }}$ & $24.2^{\operatorname{lmn}}$ & $20.4^{\circ}$ & $15.6^{\mathrm{p}}$ & $11.1^{\mathrm{q}}$ & $23.37^{\mathrm{d}}$ \\
\hline $\mathrm{CW}(10 \%)$ & $38.6^{\mathrm{a}}$ & $34.3^{\mathrm{ecd}}$ & $31.1^{\mathrm{fgh}}$ & $28.2^{\mathrm{ijk}}$ & $24.3^{\operatorname{lm}}$ & $21.4^{\text {on }}$ & $29.66^{\mathrm{c}}$ \\
\hline KMS $(0.5 \%)$ & $38.8^{\mathrm{a}}$ & $35^{\mathrm{bcd}}$ & $35.6^{\mathrm{bc}}$ & $32.8^{\text {efcd }}$ & $28.9^{\mathrm{ijh}}$ & $25.8^{\mathrm{lk}}$ & $32.81^{\mathrm{ba}}$ \\
\hline KMS $(0.6 \%)$ & $38.9^{\mathrm{a}}$ & $34.5^{\mathrm{bcd}}$ & $34.9^{\mathrm{bcd}}$ & $31.6^{\text {efgh }}$ & $27.5^{\mathrm{jk}}$ & $24.3^{\mathrm{Im}}$ & $31.95^{\mathrm{b}}$ \\
\hline
\end{tabular}




\begin{tabular}{|c|c|c|c|c|c|c|c|}
\hline $\mathrm{NaClO}_{2}(0.05 \%)$ & $39.1^{\mathrm{a}}$ & $37.2^{\mathrm{ba}}$ & $35.4^{\mathrm{bc}}$ & $32.9^{\text {efcd }}$ & $28.8^{\mathrm{ijh}}$ & $25.9^{\mathrm{lk}}$ & $33.23^{\mathrm{a}}$ \\
\hline $\mathrm{NaClO}_{2}(0.06 \%)$ & $39.0^{\mathrm{a}}$ & $37.2^{\mathrm{ba}}$ & $35^{\mathrm{bcd}}$ & $32.3^{\text {efgd }}$ & $27.8^{\mathrm{ijk}}$ & $24.1^{\mathrm{Imn}}$ & $32.57^{\mathrm{ba}}$ \\
\hline Control & $38.5^{\mathrm{a}}$ & $29.5^{\mathrm{ijgh}}$ & $21.5^{\mathrm{omn}}$ & $14.12^{\mathrm{p}}$ & $10.5^{\mathrm{q}}$ & $8.2^{\mathrm{q}}$ & $20.39^{\mathrm{e}}$ \\
\hline Mean & $38.77^{\mathrm{a}}$ & $34.03^{\mathrm{b}}$ & $31.09^{\mathrm{c}}$ & $27.46^{\mathrm{d}}$ & $23.35^{\mathrm{e}}$ & $20.11^{\mathrm{f}}$ \\
\hline
\end{tabular}

* Means with same superscript are not significantly different.

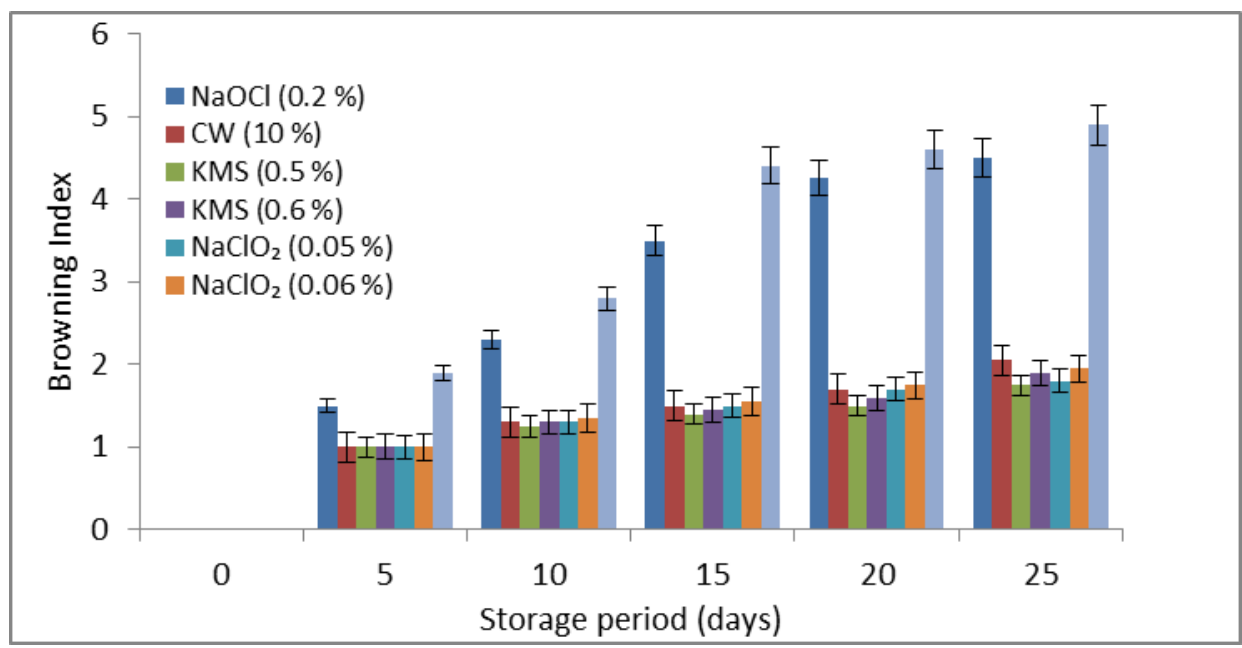

Fig 1: Effect of treatments on browning index of litchi fruits during storage $\left(2{ }^{\circ} \mathrm{C}\right.$ and $\left.85-90 \% \mathrm{RH}\right)$

Browning of litchi fruits is due to degradation of anthocyanin pigments by the activities of polyphenol oxidase as reported by Jiang et al., $2002{ }^{[7]}$. Fruits treated with KMS (0.5\%) had lowest browning index which may be due lower water loss from the fruits and also, action of $\mathrm{SO}_{2}$ which is liberated from KMS causing inhibition of PPO activity leading to no enzymatic browning. In a similar manner, Also, $\mathrm{NaClO}_{2}$ $(0.5 \%)$ showed significant result which may be due to acidic nature of sodium chlorite would have reduced the $\mathrm{pH}$ of the fruits thus intensifying the colour of litchi as well as inhibiting the PPO activity in litchi (Khunpon et al., 2011) ${ }^{[9]}$. In our study, higher concentrations of KMS $(0.6 \%)$ and sodium chlorite $(0.06 \%)$ were also used but found less effective which may be due to tissue damage (Lu et al., 2007) [11] causing leakage of substrates leading to oxidation of phenolic compounds resulting in low performance in maintaining the quality parameters of litchi fruit. In contrast, control fruits showed maximum browning index which may be due to maximum water loss because of higher metabolic activity during storage.

It was found that texture, taste, flavour and aroma of the litchi fruits were degraded during storage in spite of treatments which might be due to degradation of quality attributes causing lowering of acceptability. However, fruits treated with $\mathrm{NaClO}_{2} \quad(0.05 \%)$ showed higher overall sensory attributes on the last day of storage which might be due to better maintenance of texture and quality attributes by the treated fruits. But, in fruits treated with KMS $(0.5 \%)$, there might be development of off-flavour (sulphur flavour) in the litchi fruits (Schutte et al., 1990) [17] causing lower acceptability than the fruits treated with $\mathrm{NaClO}_{2}(0.05 \%)$.

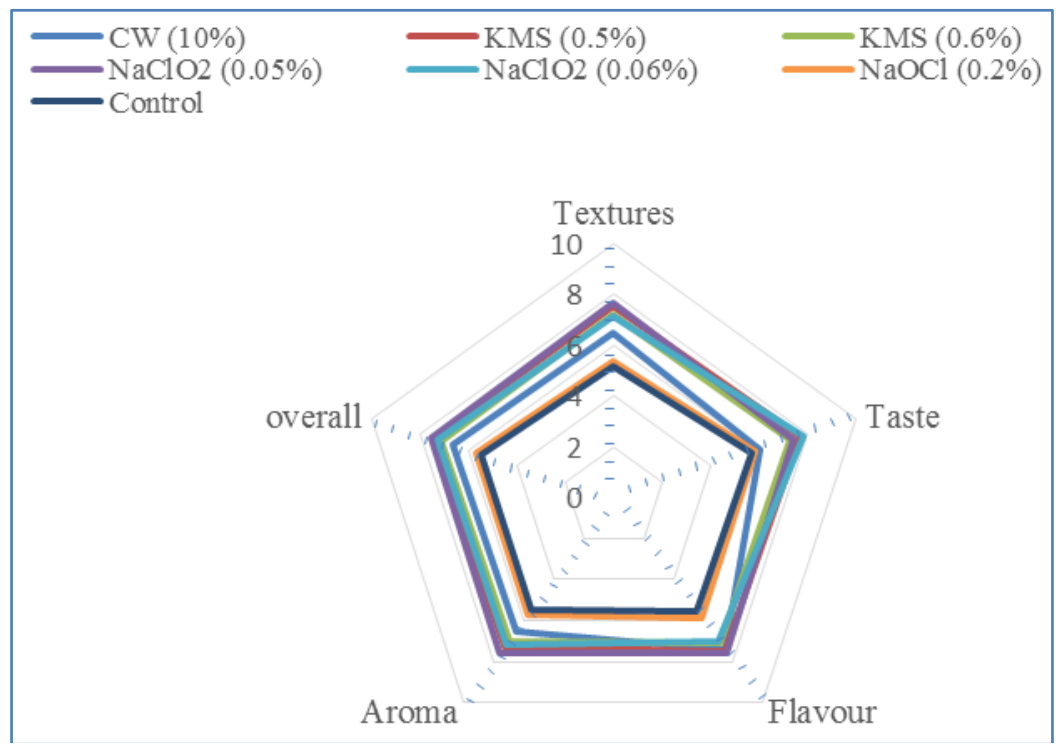

Fig 2: Sensory score of litchi fruits as influenced by different treatments on last day of storage

\section{Conclusion}

Combinational treatments of chemicals at low temperature storage were found effective for extending the shelf life of litchi fruits up to 25 days. All the treatments reduced pericarp browning but sodium hypochlorite $(0.2 \%)$ in combination with KMS $(0.5 \%)$ treated fruits was more effective in 
retaining anthocyanin, delaying loss in weight, total soluble solids and reducing sugars in the fruits leading to lowest browning index when stored at $2{ }^{\circ} \mathrm{C}$ and $85-90 \%$ relative humidity. Also, the treatment showed good overall sensory attributes among all except the fruits treated with $\mathrm{NaClO}_{2}$ $(0.05 \%)$. Therefore, application of these chemicals which are easily available, can be cost effective and as an alternative method for $\mathrm{SO}_{2}$ fumigation to maintain the quality of litchi for longer period.

\section{References}

1. Amerine MA, Dengborn RM, Roessler EB. Principles of sensory evaluation of food. In Food Science and Technology Monographs. Academic Press, New York, 1965, 338-339p.

2. Anonymous. Second Advance Estimate of Area and Production of Horticulture Crops. National Horticulture Board. Ministry of Agriculture, Government of India, Gurgaon, India. 2017. http://nhb.gov.in/areapro/2nd_Advance_Estimates_201617.pdf Accessed on 16.01.2019.

3. Baldwin EA, Nisperos MO, Chen X, Hagenmaier RD. Improving storage life of cut apple and potato with edible coating. Postharvest Biology and Technology. 1996; 9:151-163

4. Cerioni L, Rapisarda VA, Hilal M, Prado FE, RodriguezMontelongo L. Synergistic antifungal activity of sodium hypochlorite, hydrogen peroxide and cupric sulfate against Penicillium digitatum. Journal of Food Protection. 2009; 72:1660-1665.

5. Jha AK, Singh AK, Parsad US. Respiratory metabolites in Litchi chinensis Sonn. during fruit ripening and senescence. Indian Journal of Experimental Biology. 1990; 28:537-541.

6. Jiang Y. Role of anthocyanins, polyphenol oxidase and phenols in lychee pericarp browning. Journal of the Science of Food and Agriculture. 2000; 80(3):305310.

7. Jiang YM, Zhang Z, Joyce DC, Ketsa S. Postharvest biology and handling of longan fruit (Dimocarpus longan Lour.). Postharvest Biology and Technology. 2002; 26:241-252.

8. Khan AS, Ahmad N, Malik AU, Amjad M. Cold storage influences the postharvest pericarp browning and quality of litchi. International Journal of Agriculture and Biology. 2012; 14:389-394.

9. Khunpon B, Uthaibutra J, Faiyue B, Saengnil K. Reduction of enzymatic browning of harvested 'Daw' longan exocarp by sodium chlorite. Science Asia. 2011; 37:234-239.

10. Liang YS, Chen NL, Ke LS. Influence of dipping in sodium metabisulfite on pericarp browning of litchi cv. $\mathrm{Yu} \mathrm{He} r \mathrm{Pau}$ (Feizixiao). Postharvest Biology and Technology. 2012; 68:72-77.

11. Lu S, Luo Y, Turner E, Feng H. Effects of sodium chlorite as an inhibitor of enzymatic browning in apple slices. Food Chemistry. 2007; 104:824-829.

12. Marboh ES, Lal RL, Mishra DS, Goswami AK. Effect of hot water treatment and oxalic acid on colour retention and storage quality of litchi fruit cv. Rose Scented. Indian Journal of Horticulture. 2012; 69(4):484-488.

13. Mc-Evily AJ, Iyengar R, Otwell WS. Inhibition of enzymatic browning in foods and beverages. Critical Review; Food Science and Nutrition. 1992; 32:253-273.

14. Milne DL, Champ BR, Highley E, Johnson GI. Postharvest handling of avocado, mango and lychee for export from South Africa postharvest handling of tropical fruits. ACIAR Proceedings. 1994; 50:73-89.

15. Neog M, Saikia L. Control of post-harvest pericarp browning of litchi (Litchi chinensis. Sonn). Journal of Food Science and Technology. 2010; 47(1):100-104.

16. Nigam JK, Kumar K, Kumar R, Kumar R. Effect of harvesting dates, storage environments and postharvest treatments on shelf life of litchi fruits. Advances in Plant Sciences. 2000; 13(2):543-550.

17. Schutte GC, Botha T, Kotze JM. Postharvest control of decay and browning of litchi fruit by fungicide dips and paper sheets impregnated with sodium-metabisulphite. Litchi Year Book- South Africa Litchi Growers' Association. 1990; 3:10-14.

18. Sun J, Jiang Y, Wei X, Shi J, You Y, Liu H et al. Identification of (-) epicatechin as the direct substrate for polyphenol oxidase isolated from litchi pericarp. Food Research International. 2006; 39:864-870.

19. Wang JB, Wang XS, Jin ZQ. Enzymatic browning of postharvest litchi: a review. In: Dongliang $Q$ et al. (eds) Trees in Sapindaceae family, Proc 3rd IS on Longan, Litchi and other fruits. Acta Horticulturae. 2010; 863:613-617. 